\title{
OPTIMIZATION OF USE CONDITIONS FOR CATHODIC ARC NICKEL COATING DOPED WITH PHOSPHORUS
}

\author{
V.A. Lapitskaya ${ }^{1}$, T.A. Kuznetsova ${ }^{1}$, R.E. Trukhan ${ }^{1}$, A.V. Khabarava ${ }^{1}$, S.A. Chizhik, ${ }^{1,2}$,

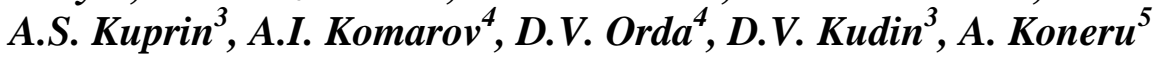 \\ ${ }^{1}$ A.V. Luikov Heat and Mass Transfer Institute of the National Academy of Sciences \\ of Belarus, Minsk, Belarus; \\ ${ }^{2}$ Presidium of the National Academy of Sciences of Belarus, Minsk, Belarus; \\ ${ }^{3}$ National Science Center "Kharkov Institute of Physics and Technology", Kharkiv, Ukraine; \\ ${ }^{4}$ Joint Institute of Mechanical Engineering of the NAS of Belarus; \\ ${ }^{5}$ Somnio Global, Novi, USA \\ E-mail: vasilinka.92@mail.ru
}

The results of tribological tests for a cathodic arc nickel coating doped with phosphorus are presented. The coating (thickness of $2 \mu \mathrm{m}$ ) is applied by a vacuum arc method from a nickel target with $6 \%$ phosphorus. The friction coefficient $\left(\mathrm{C}_{\mathrm{fr}}\right)$ was determined on the tribometer, the depth of wear $\mathrm{h}$ of the coating after tribological tests was determined by the contact profilometry method, and the specific volumetric wear $(\omega)$ was calculated. The obtained values of $\mathrm{C}_{\mathrm{fr}}, \omega$, and $\mathrm{h}$ were used to optimize the parameters of tribological tests (load and slip frequency).

\section{INTRODUCTION}

Nickel coatings containing phosphorus, due to their high hardness, wear resistance and corrosion resistance, are currently used to reduce wear of rubbing surfaces, protect the products made of steel and non-ferrous metals against corrosion [1, 2], for protection against electromagnetic interference and for MEMS [3]. In the literature, studies are mainly conducted on nickel coatings with phosphorus, obtained by electrolytic and chemical methods $[4,5]$. In order to increase corrosion resistance, electrolytic nickel coatings are applied to the surface in two layers. Such coatings with $18 \ldots 20$ at.\% of phosphorus demonstrate noticeably better corrosion resistance in comparison with pure nickel $[2,6]$. Nickel coatings with different phosphorus content have different physicochemical properties [7]. Nickel coatings electrolytically deposited in complex solutions can be brittle and have low corrosion resistance due to the ingress of sulfur, boron and other elements contained in the electrolyte into the coating. Cathodic arc coating deposition is an environmentally friendly technology in comparison with electrochemical deposition or vapor-phase metallization in a vacuum. The properties of vacuum coatings can significantly exceed those of electrolytic ones [8]. In electrolytic deposition, chloride-sulfate, acetate-chloride, nickel sulfate, magnesium sulfate and other electrolytes are used. This requires proper treatment and disposal. In the process of vapor-phase metallization in a vacuum, while obtaining ultrapure nickel coatings, poisonous carbonyl vapors are released [2]. This requires an additional complex ventilation system to completely exclude the contact of vapors with humans.

The presence of oxide films and various phases on the surface of vacuum-arc nickel coatings can create good conditions for the formation of tribofilms, which can increase their wear resistance.

Increasing the wear resistance of coatings for use at high contact pressures is one of the urgent tasks in modern tool and mechanical engineering. It is important to know under what operating conditions and contact pressures certain coatings retain their properties most effectively. Therefore, the question is raised about the optimization of these parameters before the massive use of coatings in industry.

There are several ways of parameter optimization: finite element method, Taguchi method, fuzzy logic, gray relational analysis, etc., which differ in the calculation method, choice of parameters and conditions. The most common method is gray relational analysis [9], which allows you to select parameters and conditions from several optimal ones obtained as a result of the analysis.

The goal of this paper is to study the mechanical and tribotechnical properties of the cathodic arc nickel coating doped with phosphorus, and to optimize the operating parameters using gray relational analysis.

\section{MATERIALS AND RESEARCH METHODS}

The nickel coating was applied by the cathodic arc method using the "Bulat" installation [10]. The sputtered cathode contained $6 \%$ phosphorus, the cathode arc current was $100 \mathrm{~A}$, and the bias voltage on the substrate was $-50 \mathrm{~V}$. A $2 \mu \mathrm{m}$ thick coating with the phosphorus concentration of 2 at. \% was applied to the 08X18H10T stainless steel substrate.

The morphology of the coating surface was investigated using a JSM-7001F scanning electron microscope (SEM), (JEOL, Japan). 
The coefficient of friction $\left(\mathrm{C}_{\mathrm{fr}}\right)$ and wear of the coating were determined using a multifunctional tribometer MFT5000 (Rtec Instruments, USA). The sliding frequency at the distance of $400 \mathrm{~mm}$ for 200 cycles and the load of $0.2 \ldots 2.0 \mathrm{~N}$ varied from 1 to $30 \mathrm{~Hz}$. Movement on the surface is reciprocating. A Rockwell diamond indenter with the radius of $200 \mu \mathrm{m}$ was used as a counterbody.

The contact pressure in the friction zone was determined using the web-calculator of contact stresses AMES (Advanced Mechanical Engineering Solutions) [11]. The indenter load, indenter diameter, modulus of elasticity for the coating and indenter were set. The modulus of elasticity and microhardness of the coating were determined using a Hysitron 750 Ubi nanoindenter (United States).

The width of friction tracks on the coating was determined using a MICRO-200 optical microscope (JSC Planar, Republic of Belarus); the depth (on each track in three places) and roughness of the coating were measured with a Surftest SJ-210 contact profilometer (Mitutoyo, Japan); profilograms with the length of 0.8 and $2.5 \mathrm{~mm}$, respectively, were recorded. Specific volumetric wear $(\omega)$ was calculated from the volume of material removed during the friction test, divided by the product of load and distance [12].

Optimization was performed using the gray relational analysis method in the Fuzzy Logic Toolbox MATLAB simulation package. Gray relational analysis is based on fuzzy systems in which only a piece of information is known. In the theory of gray systems, it establishes the relationship between the main factor and auxiliary factors in the system under study by comparing the reference sequence with the compared sequences, on the basis of which the best of the reduced models is determined [9].

The Fuzzy Logic Toolbox in MATLAB provides capabilities for modeling systems based on fuzzy logic. The creation of a model in this package includes the following steps: creation of membership functions, setting their ranges and form of functions, creation of the system of rules for fuzzy inference [13].

The gray-scale relational analysis in MATLAB was performed as follows:

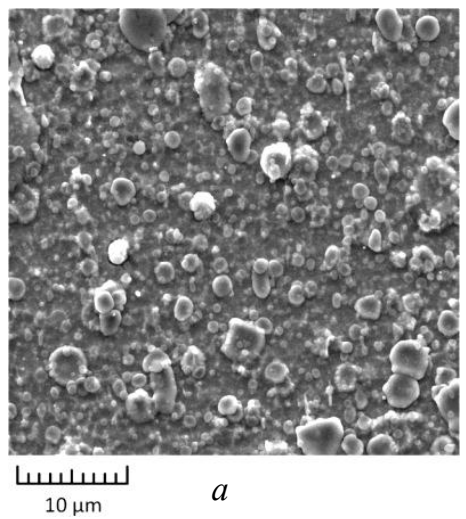

1. The data on the specific volumetric wear and the friction coefficient were normalized in accordance with the less-is-better effect using the formula [14]:

$$
x_{i}^{*}(k)=\frac{\max x_{i}(k)-x_{i}(k)}{\max x_{i}(k)-\min x_{i}(k)},
$$

where $x_{i}(k)$ is the value for the parameter of the sequence being compared; $\max x_{i}(k)$ and $\min x_{i}(k)$ are the maximum and minimum values of the sequence under study, respectively.

The goal of normalization is to bring the compared sequences to a form that makes it convenient to estimate the level of the parameter.

2. The GRC was determined by the formula [14]:

$$
\xi_{i}(k)=\frac{\Delta_{\min }+r * \Delta_{\max }}{\Delta_{0 i}(k)+r * \Delta_{\max }},
$$

where $\Delta_{0 i}=\left\|x_{0}(k)-x_{i}^{*}(k)\right\|$ is the difference in absolute values between $x_{0}(k)$ and $x_{i}^{*}(k) ; \Delta_{\min }$ and $\Delta_{\max }$ are the minimum and maximum values of the absolute deviation $\left(\Delta_{0 i}\right)$ for all the compared sequences; $r$ is the distinctive coefficient used to correct the difference in the relational coefficient and usually lies in the interval $[0 ; 1]$. The effect $\Delta_{\max }$ is controlled by the $\mathrm{r}$ value. The lower the $r$ value, the higher the distinctiveness. The value of this coefficient was taken equal to 0.5 , as in [13].

3. The Gray Relational Grade (GRG) was determined in the model created in MATLAB, as well as the ranking of the results [14].

The ranking of the results was carried out using the Microsoft Office Excel program. The operator RANK was used, an array of values for the Gray Fuzzy Grade (GFG) was selected as an argument to the function. The higher the GFG value, the higher the rank.

\section{RESULTS AND DISCUSSION}

The results of studying the morphology of a vacuum nickel coating using SEM are shown in Fig. 1. It can be seen that on the surface of the coating there is a large number of microdroplets, mostly circular in shape, the size of which varies from 1 to $4 \mu \mathrm{m}$.

At maximum magnification $(50.000 \mathrm{x})$, the coating structure consists of microdroplets less than $1 \mu \mathrm{m}$ in size, and a cellular structure is also visible.

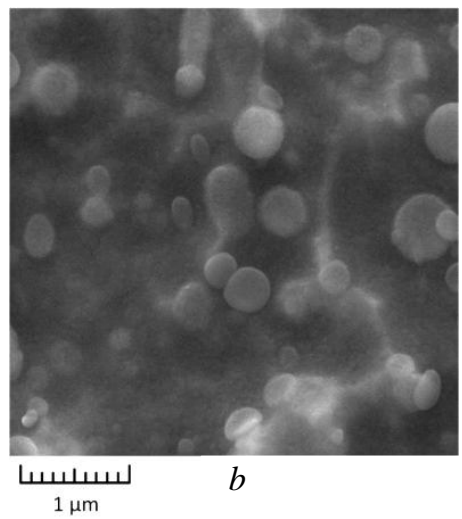


The roughness of the coating surface, measured by the profilometer, was $\mathrm{Ra}=0.163 ; \mathrm{Rq}=0.239$, and $\mathrm{Rz}=1.279 \mu \mathrm{m}$. The microhardness and elastic modulus values are 5.1 and $135 \mathrm{GPa}$, respectively.

As a result of tribotechnical tests, friction tracks were obtained on the coating surface, each of which corresponded to certain friction parameters: sliding frequency and load (Fig. 2). The dependence of the wear depth on the sliding frequency, taking into account the coating thickness, is shown in Fig. 3. Based on the obtained values, it was found that the complete wear of the vacuum nickel coating after friction occured at the loads of 1.5 and $2.0 \mathrm{~N}$ at all the frequencies of $1 \ldots 30 \mathrm{~Hz}$ (see Fig. 3). The contact pressure under such loads was 20.2 and $22.2 \mathrm{GPa}$, respectively.

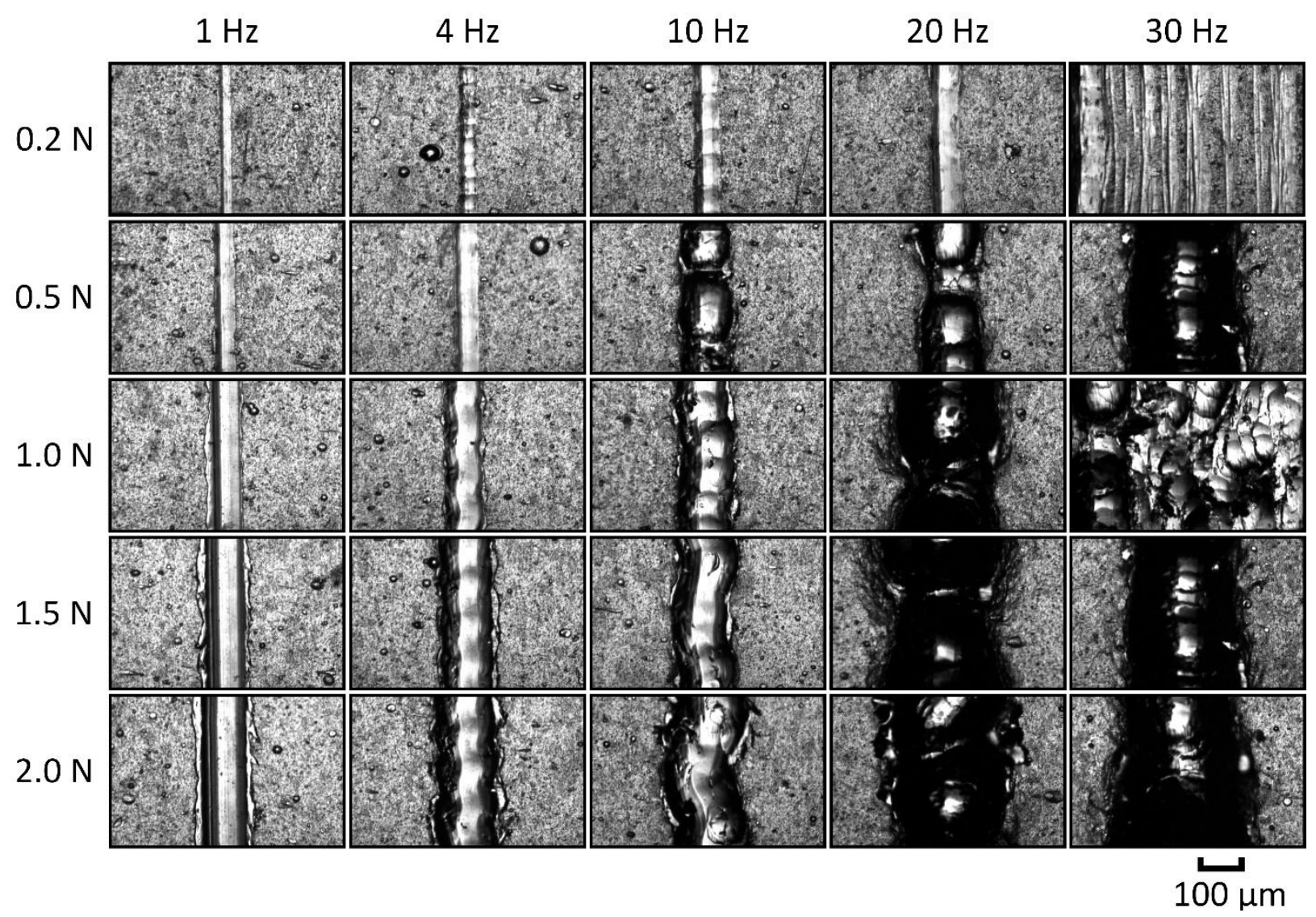

Fig. 2. Images of friction tracks on a nickel coating from an optical microscope at various parameters of tribotechnical tests

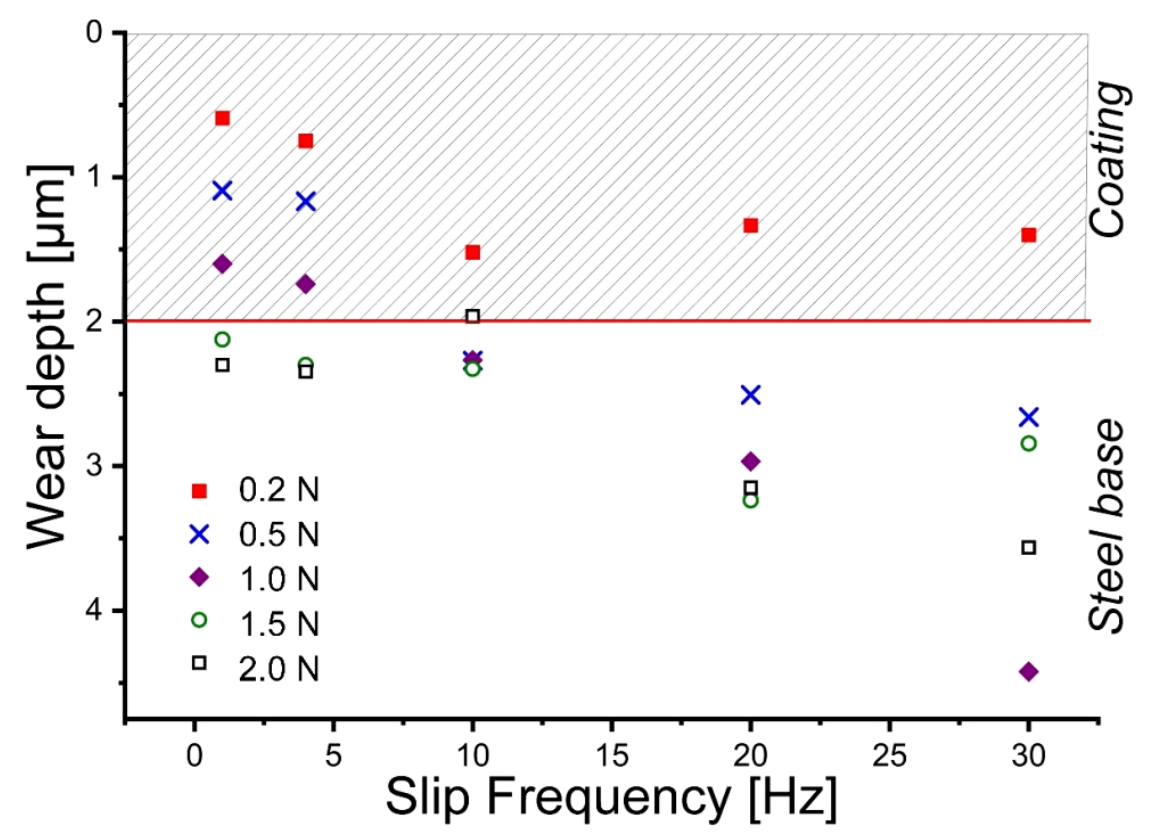

Fig. 3. Wear depth at various parameters of tribotechnical tests 
At the loads of 1.5 ..2.0 N and sliding frequency of 10 to $30 \mathrm{~Hz}$, in addition to complete wear of the coating, a change in the structure of the tracks is observed: deformation of the track lateral edges occurs, sagging appears, inside the tracks there is a significant unevenness of the wear depth. Such changes occur at the complete wear of the coating and further wear of the steel substrate. The load of $0.2 \mathrm{~N}$ (contact pressure of $10.3 \mathrm{GPa}$ ) at all the frequencies does not lead to complete wear of the coating, while the track depth varies in the range from $0.59 \mu \mathrm{m}$ (at $1 \mathrm{~Hz}$ ) to $1.40 \mu \mathrm{m}$ (at $30 \mathrm{~Hz}$ ).

Complete wear of the coating does not occur at the sliding frequencies of 1 and $4 \mathrm{~Hz}$ up to the load of $1.0 \mathrm{~N}$ (contact pressure of $17.6 \mathrm{GPa}$ ) inclusively. The maximum depth of the coating wear at the frequencies of 1 and $4 \mathrm{~Hz}$ is $1.74 \mu \mathrm{m}$. At the load of $0.5 \mathrm{~N}$ (contact pressure of $14.0 \mathrm{GPa}$ ), sliding frequency of $10 \mathrm{~Hz}$ or more, complete wear of the coating also occurs.

The results of determining the friction coefficient and calculating the specific volumetric wear for various parameters of tribotechnical tests are shown in Fig. 4. In the literature [5], the values of the friction coefficient are presented within the range from 0.2 to 0.7 for the nickel coatings deposited by the electrolytic method at the loads of 30 and $40 \mathrm{~N}$. In accordance with the results of the study on the cathodic arc nickel coating doped with phosphorus, the friction coefficient varies from

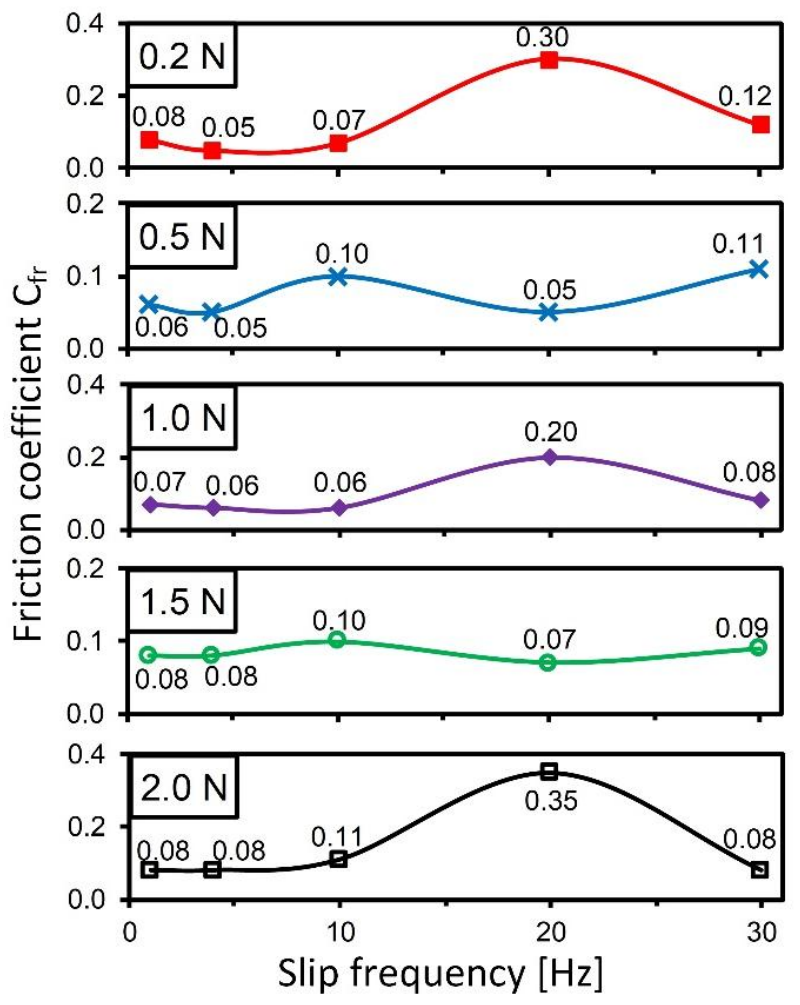

$a$

Fig. 4. Friction coefficient (a) and specific volumetric wear (b) at various parameters of tribotechnical tests

GRG data were obtained from the gray relational coefficients. An additional condition was also the fact that if the wear depth $\mathrm{h}$ exceeded the coating thickness $(2 \mu \mathrm{m})$, then the value of this experiment decreased and the GRG coefficient for such experiments also became lower. In Table 1, the experimental conditions,
0.05 to 0.35 . The maximum value of the friction coefficient was obtained at the load of $2 \mathrm{~N}$ and sliding frequency of $20 \mathrm{~Hz}$. At the load of $0.2 \mathrm{~N}$, at which there is no complete wear of the coating at all the sliding frequencies, the friction coefficient remains in the range from 0.05 (at $4 \mathrm{~Hz}$ ) to 0.30 (at $20 \mathrm{~Hz}$ ).

The maximum wear of $123.91 \cdot 10^{-13} \mathrm{~m}^{3} /(\mathrm{N} \cdot \mathrm{m})$ occurs at the load of $1.0 \mathrm{~N}$ and rate of $30 \mathrm{~Hz}$ (see Fig. 4). The friction coefficient in this case was 0.08 . The minimum value of the specific volumetric wear of $3.11 \cdot 10^{-13} \mathrm{~m}^{3} /(\mathrm{N} \cdot \mathrm{m})$ was obtained at the load of $0.2 \mathrm{~N}$ and rate of $1 \mathrm{~Hz}$. The values of the specific volumetric wear, in addition to the sliding frequency and load, significantly depend on the uniformity of the wear depth along the entire length of the track. Based on the results obtained, using gray relational analysis, the friction modes were evaluated under various experimental conditions and the optimal modes were selected under the following conditions: the lower the friction coefficient, depth of wear and specific volumetric wear, the better. For this, the experimental data were normalized using the formula (1) and, on their basis, GRC were calculated using the formula (2). Then, in the MATLAB program in the Fuzzy Logic Toolbox package, a fuzzy inference system was formed for three input parameters $\left(\omega, \mathrm{C}_{\mathrm{fr}}\right.$, and $\left.\mathrm{h}\right)$.

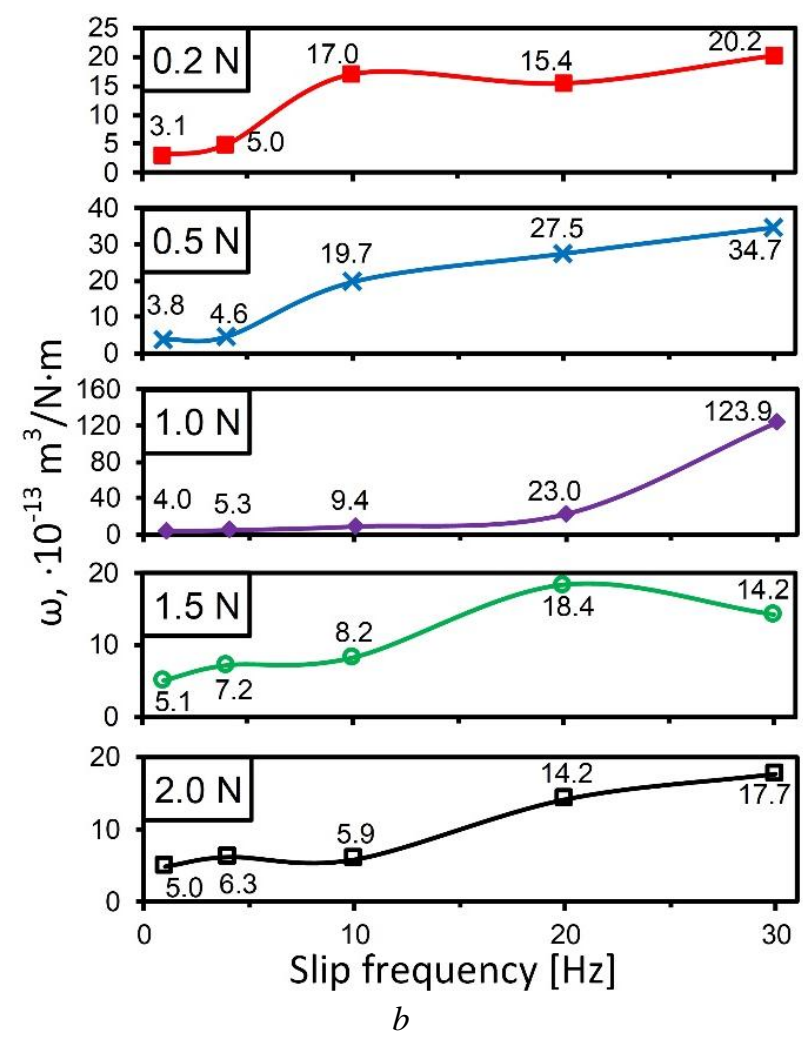

experimental results, GRG and estimations are described. With the help of Table 1 , the order of the experiments based on the obtained values of the GRG coefficient can be established. The closer GRG is to one, the better. 
Table 1

Experimental conditions, their results and evaluation

\begin{tabular}{|c|c|c|c|c|c|c|c|c|c|c|}
\hline Experiment No. & $\mathrm{v}, \mathrm{Hz}$ & $\mathrm{P}, \mathrm{H}$ & $\begin{array}{c}\omega, \cdot 10^{-13} \\
\mathrm{~m}^{3} /(\mathrm{N} \cdot \mathrm{m})\end{array}$ & $\mathrm{h}, \mu \mathrm{m}$ & $\mathrm{C}_{\mathrm{fr}}$ & $\mathrm{GRC} \omega$ & $\mathrm{GRC}_{\mathrm{Cr}}$ & $\mathrm{GRC}_{\mathrm{h}}$ & GRG & Order \\
\hline 1 & 1 & 0.2 & 3.11 & 0.59 & 0.08 & 1.000 & 0.833 & 1.000 & 0.935 & 1 \\
\hline 2 & 1 & 0.5 & 3.84 & 1.09 & 0.06 & 0.988 & 0.938 & 0.793 & 0.898 & 4 \\
\hline 3 & 1 & 1.0 & 4.00 & 1.60 & 0.07 & 0.986 & 0.882 & 0.655 & 0.845 & 5 \\
\hline 4 & 1 & 1.5 & 5.05 & 2.12 & 0.08 & 0.969 & 0.833 & 0.556 & 0.667 & 12 \\
\hline 5 & 1 & 2.0 & 4.95 & 2.30 & 0.08 & 0.970 & 0.833 & 0.528 & 0.668 & 11 \\
\hline 6 & 4 & 0.2 & 4.95 & 0.75 & 0.05 & 0.970 & 1.000 & 0.923 & 0.932 & 2 \\
\hline 7 & 4 & 0.5 & 4.59 & 1.17 & 0.05 & 0.976 & 1.000 & 0.768 & 0.905 & 3 \\
\hline 8 & 4 & 1.0 & 5.33 & 1.74 & 0.06 & 0.965 & 0.938 & 0.625 & 0.837 & 6 \\
\hline 9 & 4 & 1.5 & 7.15 & 2.30 & 0.08 & 0.937 & 0.833 & 0.528 & 0.657 & 14 \\
\hline 10 & 4 & 2.0 & 6.26 & 2.35 & 0.08 & 0.950 & 0.833 & 0.521 & 0.661 & 13 \\
\hline 11 & 10 & 0.2 & 17.04 & 1.52 & 0.07 & 0.813 & 0.882 & 0.673 & 0.796 & 7 \\
\hline 12 & 10 & 0.5 & 19.68 & 2.27 & 0.10 & 0.785 & 0.750 & 0.533 & 0.572 & 21 \\
\hline 13 & 10 & 1.0 & 9.38 & 2.27 & 0.06 & 0.906 & 0.938 & 0.533 & 0.676 & 10 \\
\hline 14 & 10 & 1.5 & 8.23 & 2.33 & 0.10 & 0.922 & 0.750 & 0.524 & 0.617 & 18 \\
\hline 15 & 10 & 2.0 & 5.91 & 1.96 & 0.11 & 0.956 & 0.714 & 0.583 & 0.739 & 8 \\
\hline 16 & 20 & 0.2 & 15.44 & 1.33 & 0.30 & 0.831 & 0.375 & 0.721 & 0.640 & 15 \\
\hline 17 & 20 & 0.5 & 27.46 & 2.51 & 0.05 & 0.713 & 1.000 & 0.499 & 0.636 & 16 \\
\hline 18 & 20 & 1.0 & 23.02 & 2.97 & 0.20 & 0.752 & 0.500 & 0.446 & 0.479 & 23 \\
\hline 19 & 20 & 1.5 & 18.36 & 3.24 & 0.07 & 0.798 & 0.882 & 0.419 & 0.628 & 17 \\
\hline 20 & 20 & 2.0 & 14.22 & 3.15 & 0.35 & 0.845 & 0.333 & 0.428 & 0.460 & 24 \\
\hline 21 & 30 & 0.2 & 20.21 & 1.40 & 0.12 & 0.779 & 0.682 & 0.703 & 0.720 & 9 \\
\hline 22 & 30 & 0.5 & 34.68 & 2.66 & 0.11 & 0.657 & 0.714 & 0.481 & 0.526 & 22 \\
\hline 23 & 30 & 1.0 & 123.91 & 4.42 & 0.08 & 0.333 & 0.833 & 0.333 & 0.428 & 25 \\
\hline 24 & 30 & 1.5 & 14.21 & 2.84 & 0.09 & 0.845 & 0.789 & 0.459 & 0.612 & 20 \\
\hline 25 & 30 & 2.0 & 17.74 & 3.56 & 0.08 & 0.805 & 0.833 & 0.392 & 0.613 & 19 \\
\hline
\end{tabular}

Table 2

Ranking by parameter levels

\begin{tabular}{|c|c|c|c|c|c|c|c|c|c|}
\hline Experiment No. & $v, \mathrm{~Hz}$ & $\mathrm{P}, \mathrm{N}$ & $\mathrm{GRG}$ & Rank & Experiment No. & $\mathrm{P}, \mathrm{H}$ & $v, \mathrm{~Hz}$ & GRG & Rank \\
\hline 1 & 1 & 0.2 & 0.935 & 1 & 1 & 0.2 & 1 & 0.935 & 1 \\
\hline 2 & 1 & 0.5 & 0.898 & 2 & 6 & 0.2 & 4 & 0.932 & 2 \\
\hline 3 & 1 & 1 & 0.845 & 3 & 11 & 0.2 & 10 & 0.796 & 3 \\
\hline 4 & 1 & 1.5 & 0.667 & 5 & 16 & 0.2 & 20 & 0.640 & 5 \\
\hline 5 & 1 & 2 & 0.668 & 4 & 21 & 0.2 & 30 & 0.720 & 4 \\
\hline 6 & 4 & 0.2 & 0.932 & 1 & 2 & 0.5 & 1 & 0.898 & 2 \\
\hline 7 & 4 & 0.5 & 0.905 & 2 & 7 & 0.5 & 4 & 0.905 & 1 \\
\hline 8 & 4 & 1 & 0.837 & 3 & 12 & 0.5 & 10 & 0.572 & 4 \\
\hline 9 & 4 & 1.5 & 0.657 & 5 & 17 & 0.5 & 20 & 0.636 & 3 \\
\hline 10 & 4 & 2 & 0.661 & 4 & 22 & 0.5 & 30 & 0.526 & 5 \\
\hline 11 & 10 & 0.2 & 0.796 & 1 & 3 & 1 & 1 & 0.845 & 1 \\
\hline 12 & 10 & 0.5 & 0.572 & 5 & 8 & 1 & 4 & 0.837 & 2 \\
\hline 13 & 10 & 1 & 0.676 & 3 & 13 & 1 & 10 & 0.676 & 3 \\
\hline 14 & 10 & 1.5 & 0.617 & 4 & 18 & 1 & 20 & 0.479 & 4 \\
\hline 15 & 10 & 2 & 0.739 & 2 & 23 & 1 & 30 & 0.428 & 5 \\
\hline 16 & 20 & 0.2 & 0.640 & 1 & 4 & 1.5 & 1 & 0.667 & 1 \\
\hline 17 & 20 & 0.5 & 0.636 & 2 & 9 & 1.5 & 4 & 0.657 & 2 \\
\hline 18 & 20 & 1 & 0.479 & 4 & 14 & 1.5 & 10 & 0.617 & 4 \\
\hline 19 & 20 & 1.5 & 0.628 & 3 & 19 & 1.5 & 20 & 0.628 & 3 \\
\hline 20 & 20 & 2 & 0.460 & 5 & 24 & 1.5 & 30 & 0.612 & 5 \\
\hline 21 & 30 & 0.2 & 0.720 & 1 & 5 & 2 & 1 & 0.668 & 2 \\
\hline 22 & 30 & 0.5 & 0.526 & 4 & 10 & 2 & 4 & 0.661 & 3 \\
\hline 23 & 30 & 1 & 0.428 & 5 & 15 & 2 & 10 & 0.739 & 1 \\
\hline 24 & 30 & 1.5 & 0.612 & 3 & 20 & 2 & 20 & 0.460 & 5 \\
\hline 25 & 30 & 2 & 0.613 & 2 & 25 & 2 & 30 & 0.613 & 4 \\
\hline & & & & & & & & \\
\hline
\end{tabular}


Thus, the most suitable operating conditions for the cathodic arc nickel coating doped with phosphorus $2 \mu \mathrm{m}$ thick are the parameters corresponding to the tribotechnical tests 6 (frequency $4 \mathrm{~Hz}$, load 0.2), 7 (frequency $4 \mathrm{~Hz}$, load $0.5 \mathrm{~N}$ ), and 1 (frequency $1 \mathrm{~Hz}$, load $0.2 \mathrm{~N}$ ), which provide its maximum life.

In accordance with the obtained GRG coefficients, ranking within each load level and slip frequency was performed (Table 2). For this, the GRG coefficients were used from Table 1 . Then they were divided into the groups, in which there was one constant parameter (either frequency or load), and another one was variable.

Then, using the RANK operator in Microsoft Office Excel, within each group, the GRG values were assigned ranks from 1 to 5 , where rank 1 is considered the best.

In Table 2, it is shown that under constant loads, the optimal values of specific volumetric wear and friction coefficient are observed at the rates of 1 and $4 \mathrm{~Hz}$. In the case of constant frequencies, the minimum forces are optimal for 1,4 , and $20 \mathrm{~Hz}$, and for 10 and $30 \mathrm{~Hz}$, the following is observed: at the frequency of $10 \mathrm{~Hz}$, the optimal load value is $-0.2 \mathrm{~N}$ followed by $2 \mathrm{~N}$; for the rate of $30 \mathrm{~Hz}$, the optimal load is 0.2 and $2 \mathrm{~N}$, but at the load of $2 \mathrm{~N}$, complete wear of the coating occurs.

Also, an averaged assessment of frequencies and loads was carried out by determining the average indicators $\mathrm{GRG}_{\mathrm{av}}$ for each value of rate and load separately (Table 3). From Table 1, all the values of $\mathrm{GRG}_{\mathrm{av}}$ corresponding to a certain level of load or frequency were selected, and their average value was found. For example, when searching for an average value of the load $0.2 \mathrm{~N}$, the GRG values were taken from the experiments $1,6,11,16$, and 21 (see Table 1). On the basis of the averaged data, it was found that the optimal values are a sliding frequency of $1 \mathrm{~Hz}$ and load of $0.2 \mathrm{~N}$. The effect of frequency and load on coating wear and the coefficient of friction is determined from the difference between the maximum and minimum averaged values of $\mathrm{GRG}_{\mathrm{av}}$ from Table 3: a large difference corresponds to a greater influence of the input parameter on the result. In accordance with the results of gray relational analysis, the greatest influence has the sliding frequency during friction, as the difference between the maximum and minimum $\mathrm{GRG}_{\mathrm{av}}$ (see Table 3 ) is higher for the frequency in comparison with the same difference for the load.

Table 3

Values of average ratings at different levels of load and test speed

\begin{tabular}{|c|c|c|c|}
\hline Frequency $v, \mathrm{~Hz}$ & $\mathrm{GRG}_{\mathrm{av}}$ & Load P, N (Contact pressure, GPa) & $\mathrm{GRG}_{\mathrm{av}}$ \\
\hline 1 & 0.803 & $0.2(10.3)$ & 0.805 \\
\hline 4 & 0.798 & $0.5(14.0)$ & 0.707 \\
\hline 10 & 0.680 & $1.0(17.6)$ & 0.653 \\
\hline 20 & 0.567 & $1.5(20.2)$ & 0.636 \\
\hline 30 & 0.579 & $2.0(22.2)$ & 0.628 \\
\hline Difference & 0.234 & Difference & 0.176 \\
\hline
\end{tabular}

\section{CONCLUSIONS}

Tribotechnical tests of a vacuum-arc nickel coating doped with phosphorus were carried out at various loads from 0.2 to $2.0 \mathrm{~N}$ and sliding frequency from 1 to $30 \mathrm{~Hz}$. The coefficient of friction and the depth of wear were determined. The specific volumetric wear was calculated.

It is shown that the value of coating wear depends on the sliding frequency and load, as well as the uniformity of wear depth along the entire length of the track.

It was found that only at the load of $0.2 \mathrm{~N}$, there was no complete wear of the coating at all sliding frequencies. Specific volumetric wear in this case varied from $3.11 \cdot 10^{-13} \mathrm{~m}^{3} /(\mathrm{N} \cdot \mathrm{m})$ (at $\left.1 \mathrm{~Hz}\right)$ to $20.21 \cdot 10^{-13} \mathrm{~m}^{3} /(\mathrm{N} \cdot \mathrm{m})$ (at $30 \mathrm{~Hz}$ ). The maximum wear $123.91 \cdot 10^{-13} \mathrm{~m}^{3} /(\mathrm{N} \cdot \mathrm{m})$ occurs at the load of $0.5 \mathrm{~N}$ and the rate of $30 \mathrm{~Hz}$. The friction coefficient ranged from 0.05 to 0.35 . The maximum $\mathrm{C}_{\mathrm{fr}}$ value of 0.35 was obtained at the load of $2 \mathrm{~N}$ and frequency of $20 \mathrm{~Hz}$.

On the basis of the obtained experimental data on the friction coefficient and specific volumetric wear, using gray relational analysis, the parameters of tribotechnical tests were optimized in accordance with the following criterion: the lower the friction coefficient $\mathrm{C}_{\mathrm{fr}}$ and specific volumetric wear $\omega$, the better, provided that the depth of wear $h$ does not exceed the coating thickness $(2 \mu \mathrm{m})$. The optimization results show that the sliding frequency during friction has the greatest influence on $\mathrm{C}_{\mathrm{fr}}$ and $\omega$. The optimal load for a cathodic arc nickel coating doped with phosphorus is $0.2 \mathrm{~N}$. The sliding frequency in this case should be no more than $1 \mathrm{~Hz}$.

The obtained optimal operating parameters make it possible to use a vacuum nickel coating doped with phosphorus (2 at.\%) to protect the friction units for which the contact stress in the friction zone does not exceed $10 \mathrm{GPa}$.

\section{ACKNOWLEDGEMENTS}

The work was supported by the Belarusian Republican Foundation for Fundamental Research (Project F20M-083).

\section{REFERENCES}

1. I.R. Aslanyan, L.Sh. Schuster. Wear of NiP coatings // Bulletin of the Samara Scientific Center of the Russian Academy of Sciences. Mechanics and mechanical engineering. 2011, N 4 (3), p. 951-954.

2. V.A. Lapitskaya, T.A. Kuznetsova, A.V. Khabarava, R.E. Trukhan, S.A. Chizhik, K.I. Delendik, O.L. Voitik, A.S. Kuprin, D.V. Kudin, A. Koneru, M.A. Bortnitskaya. Effect of annealing on the morphology and mechanical properties of phosphorusdoped nickel coatings obtained by cathodic arc evaporation // Journal of Physics: Conference Series, 2021, N 1954 (1), p. 012028. 
3. P. Sahoo, S.K. Das. Tribology of electroless nickel coatings - A review // Materials and Design. 2011, N 32, p. 1760-1775.

4. N.K. Myshkin, A.Ya. Grigoriev, D.M. Gutsev, M. Ignat, E. Chainet, V. Grandvallet, J. Sautel. Tribotechnical properties of thin galvanic and chemically deposited Ni-P coatings on copper // Friction and Wear. 2010, v. 31, N 6, p. 544-551.

5. M. Palaniappa, S.K. Seshadri. Friction and wear behavior of electroless Ni-P and Ni-W-P alloy coatings // Wear. 2008, N 265, p. 735-740.

6. M. Yan, H.G. Ying, T.Y. Ma. Improved microhardness and wear resistance of the as-deposited electroless Ni-P coating // Surface and Coatings Technology. 2008, N 202, p. 5909-5913.

7. M. Crobu, A. Scorciapino, B. Elsener, A. Rossi. The corrosion resistance of electroless deposited nanocrystalline Ni-P alloys // Electrochimica Acta. 2008, N 53, p. 3364-3370.

8. T.A. Kuznetsova, M.A. Andreev, L.V. Markova, V.A. Chekan. Wear resistance of composite chrome coatings with additives of utlradispersed diamonds // Journal of Friction and Wear. 2001, v. 22, N 4, p. 423 428.

9. J. Deng. Introduction to grey system theory // The Journal of Grey System. 1989, N 1, p. 1-24.
10. A.S. Kuprin, T.A. Kuznetsova, A. Gilewicz, G.N. Tolmachova, V.D. Ovcharenko, S.O. Abetkovskaia, T.I. Zubar, A.L. Khudoley, S.A. Chizhik, O. Lupicka, B. Warcholinski. Tribological properties of vacuum arc $\mathrm{Cr}-\mathrm{O}-\mathrm{N}$ coatings in macro- and microscale // Problems of Atomic Science and Technology. 2016, N 6(22), p. 211-214.

11. Advanced Mechanical Engineering Solutions/ Hertzian Contact Stress Calculator / Calculator // http://www.amesweb.info/HertzianContact/HertzianCon tact.aspx.

12. T.A. Kuznetsova, V.A. Lapitskaya, B. Warholinski, A. Gilevich, S.A. Chizhik. Friction and wear testing of $\mathrm{ZrN}$ coatings under microcontact conditions using atomic force microscopy // Friction and Wear. 2020, v. 41, N 4, p. 399-408.

13. V.S. Tarasyan. Fuzzy Logic Toolbox for Matlab: Textbook. Yekaterinburg: "Publishing house of USUPS", 2013, 112 p.

14. A. Mukhopadhyay, S. Duari, T.K. Barman, P. Sahoo. Tribological Performance Optimization of Electroless Ni-B Coating under Lubricated Condition using Hybrid Grey Fuzzy Logic // Journal of The Institution of Engineers (India): Series D. 2016, N 97, p. 215-231.

Article received 17.08.2021

\section{ОПТИМИЗАЦИЯ УСЛОВИЙ ЭКСПЛУАТАЦИИ КАТОДНО-ДУГОВОГО НИКЕЛЕВОГО ПОКРЫТИЯ, ЛЕГИРОВАННОГО ФОСФОРОМ}

\section{В.А. Лапицкая, Т.А. Кузнецова, Р.Э. Трухан, А.В. Хабарова, С.А. Чижик, А.С. Куприн, А.И. Комаров, Д.В. Орда, Д.В. Кудин, А. Копеги}

Представлены результаты триботехнических испытаний катодно-дугового никелевого покрытия, легированного фосфором. Покрытие толщиной 2 мкм нанесено вакуумно-дуговым методом из никелевой мишени с 6\% фосфора. На трибометре определены коэффициенты трения $\left(\mathrm{k}_{\text {тр }}\right)$, методом контактной профилометрии определена глубина износа (h) покрытия после триботехнических испытаний, рассчитан удельный объемный износ $(\omega)$. По полученным значениям $\mathrm{k}_{\mathrm{rp}}$, $\omega \mathrm{h} \mathrm{h}$ проведена оптимизация параметров триботехнических испытаний: нагрузки и частоты скольжения.

\section{ОПТИМІЗАЦІЯ УМОВ ЕКСПЛУАТАЦІЇ КАТОДНОГО ДУГОВОГО НІКЕЛЕВОГО ПОКРИТТЯ, ЛЕГОВАНОГО ФОСФОРОМ}

\section{В.А. Лапицька, Т.А. Кузнецова, Р.Е. Трухан, А.В. Хабарова, С.А. Чижик, О.С. Купрін, А.І. Комаров, Д.В. Орда, Д.В. Кудін, А. Копеги}

Представлено результати триботехнічних випробувань катодно-дугового нікелевого покриття, легованого фосфором. Покриття товщиною 2 мкм нанесено катодно-дуговим методом з нікелевої мішені 3 6\% фосфору. На трибометрі визначені коефіцієнти тертя $\left(\mathrm{k}_{\text {тр }}\right)$, методом контактної профілометрії визначена глибина зносу $(\mathrm{h})$ покриття після триботехнічних випробувань, розрахований питомий об'ємний знос $(\omega)$. За отриманими значеннями $\mathrm{k}_{\mathrm{rp}}$, $\omega$ та $\mathrm{h}$ проведена оптимізація параметрів триботехнічних випробувань: навантаження та частоти ковзання. 